\title{
Preliminary Evaluation of Animal Bone Char as Potential Metal Stabilization Agent in Metal Contaminated Soil
}

\author{
Evelin Gruden, Peter Bukovec and Marija Zupančič*
}

\author{
Faculty of Chemistry and Chemical Technology, University of Ljubljana, Večna pot 113, SI 1000 Ljubljana, Slovenia \\ * Corresponding author: E-mail: marija.zupancic@fkkt.uni-lj.si,
}

Phone: +38614798531

Received: 04-09-2016

For Cutting Edge 2017

\begin{abstract}
The aim of this study was to evaluate the potential effect of animal bone char (ABC) addition on metal mobility in mine tailings. The mobility of metals after addition of $\mathrm{ABC}$ to tailings at four different application rates $(0.6 \mathrm{~g}, 1.2 \mathrm{~g}, 1.8 \mathrm{~g}$ and $3.6 \mathrm{~g}$ ABC per $100 \mathrm{~g}$ of tailings) was evaluated by Toxicity Characteristic Leaching Procedure (TCLP) one step extraction. The obtained results indicated that the mobility of $\mathrm{Pb}, \mathrm{Cr}$ and $\mathrm{Cd}$ gradually decreased with increasing quantity of added ABC. According to the TCLP, mobile concentrations of $\mathrm{Pb}$ in tailings exceeded threshold values for almost eight times. After ABC addition, $\mathrm{Pb}$ TCLP-extractable concentrations decreased from $39 \mathrm{mg} \mathrm{L}^{-1}$ in tailings to lower than the TCLP limit values of $5 \mathrm{mg} \mathrm{L}^{-1}$ at all $\mathrm{ABC}$ application rates, except in mixtures with the lowest addition of $\mathrm{ABC}$. We concluded that $\mathrm{ABC}$ could be a successful metal stabilization agent for multi-metal contaminated soil, although attention should be paid at highly As contaminated soil.
\end{abstract}

Keywords: Animal bone char, metal stabilization, phosphate, mine tailings

\section{Introduction}

The contamination of soil with $\mathrm{Pb}$ is an important ecological problem worldwide whereas mining is among the main sources of $\mathrm{Pb}$ contamination in mine areas. ${ }^{1}$ Contaminated mine sites are poorly developed soils, depleted of organic matter and nutrients and are characterised by their excessive metal contents. ${ }^{2}$ In the past, large amounts of mine wastes were dumped near the sites where they were produced and dispersed into nearby soils, crops and ecosystem..$^{3-4}$ The accumulation of metals in soil may have serious consequences for animal and human health through the food chain, groundwater, plant growth and microorganism diversity. ${ }^{4-5}$

In situ chemical immobilization is a promising green and cost effective soil remediation technique where mobile metal chemical species are transformed into less mobile ones by adding different amendments. ${ }^{5-6}$ Phosphate amendments have been shown to be highly effective to reduce metal mobility and bioavailability. Many metals ( $\mathrm{Pb}, \mathrm{Zn}, \mathrm{Cd}, \mathrm{Cu}$ and others) can precipitate with phosphate sources as relatively insoluble metal phosphate species.
$\mathrm{Pb}$ can be mainly converted into insoluble forms, such as pyromorphite $\left(\mathrm{Pb}_{5}\left(\mathrm{PO}_{4}\right)_{3} \mathrm{OH}\right) .{ }^{1,7-8}$

Animal bone char $(\mathrm{ABC})$ is a granular material, rich of phosphates, that is produced by animal bone pyrolysis. ${ }^{9-10}$ It mainly contains about $70-76 \%$ of biological, relatively crystalline calcium hydroxyapatite $\left(\mathrm{Ca}_{5}\left(\mathrm{PO}_{4}\right)_{3}\right.$ $(\mathrm{OH}), 9-11 \%$ of organic carbon and 7-9\% of $\mathrm{CaCO}_{3}{ }^{11-12}$ Few previous studies highlighted the potential use of $A B C$ as a green and low-cost $\mathrm{P}-$ amendment for $\mathrm{Pb}$ and $\mathrm{Zn}$ immobilisation in contaminated soil. ${ }^{9,13}$ However the use of $\mathrm{ABC}$ as a metal stabilization agents in multi-metal contaminated soil has rarely been reported.

In this research we investigated the use of $A B C$ as metal immobilization agents and potential remediation solution for degraded metal contaminated area as mine tailings.

\section{Experimental}

In this study the mine tailings from Sasa zinc and lead mine in Macedonia were used as an example of metal 
contaminated poorly developed mine area soil. The tailings were previously air dried and analyzed for their physical and chemical properties. The tailings had a loamy sand (LS) texture (74.9\% sand, $17.4 \%$ silt and $7.7 \%$ clay). The principal crystalline tailings mineral phases were pyrite $\left(\mathrm{FeS}_{2}\right)$, quartz $\left(\mathrm{SiO}_{2}\right)$, epidote $\left(\mathrm{Ca}_{2} \mathrm{Al}_{2} \mathrm{FeSi}_{3} \mathrm{O}_{13} \mathrm{H}\right)$, clinochlore $\left(\mathrm{Mg}_{3.75} \mathrm{Fe}^{2+}{ }_{1.25} \mathrm{Si}_{3} \mathrm{Al}_{2} \mathrm{O}_{10}(\mathrm{OH})_{8}\right)$, cordierite $\left(\mathrm{Na}_{0.47}\left(\mathrm{Mg}_{0.76} \mathrm{Fe}_{1.1} \mathrm{Li}_{0.14}\right)\left(\mathrm{Al}_{3.6} \mathrm{Be}_{0.4}\right) \mathrm{Si}_{5} \mathrm{O}_{18}\left(\mathrm{H}_{2} \mathrm{O}\right)_{0.8}\right)$, calcite $\left(\mathrm{CaCO}_{3}\right)$ and mica $\left(\mathrm{K}\left(\mathrm{Mg}_{2.665} \mathrm{Li}_{0.225} \mathrm{Na}_{0.110}\right)\left(\mathrm{Si}_{3.312} \mathrm{Fe}_{0.688} \mathrm{O}_{10}\right) \mathrm{F}_{2}\right)$. The total element concentration in tailings was determined as the content of elements soluble in aqua regia according to SIST ISO 11466:1996. The mobility of elements was evaluated according to the SIST EN 12457-4 one-stage batch test (water extraction, $\mathrm{S} / \mathrm{L}=1: 10$ ) and Toxicity Characteristic Leaching Procedure - TCLP. ${ }^{14}$ To classify and quantify the metal fractionation in tailings, the modified BCR sequential extraction procedure was conducted. ${ }^{15}$ Exchangeable fraction was evaluated on $1 \mathrm{~g}$ of tailings by extraction with $40 \mathrm{~mL}$ of $0.11 \mathrm{~mol} \mathrm{~L}^{-1}$ acetic acid solution, reducible fraction with $40 \mathrm{~mL}$ of $0.5 \mathrm{~mol} \mathrm{~L}^{-1} \mathrm{NH}_{2} \mathrm{OH}$. $\mathrm{HCl}$, oxidizable fraction with $10 \mathrm{~mL}$ of $30 \% \mathrm{H}_{2} \mathrm{O}_{2}$ and residual fraction with $6 \mathrm{~mL}$ of $\mathrm{HCl}, 2 \mathrm{~mL}$ of $\mathrm{HNO}_{3}$ and $2 \mathrm{~mL}$ of HF.

The animal bone char $(\mathrm{ABC})$ was air dried and powdered by planetary mill. The physicochemical properties of tailings and $\mathrm{ABC}$ are outlined in Table 1.

To immobilize metals in contaminated soil sample, mixtures of tailings with $\mathrm{ABC}$ were prepared. $\mathrm{ABC}$ was added to tailings at four different application rates: $0.59 \mathrm{~g}$,
$1.19 \mathrm{~g}, 1.82 \mathrm{~g}$ and $3.64 \mathrm{~g} \mathrm{ABC}$ per $100 \mathrm{~g}$ of tailings. To achieve sufficient homogenization, the mixtures were prepared as water suspensions, shaken by a mechanical shaker for $1 \mathrm{~h}$ and slowly air dried. All of the experiments were carried out in triplicate.

The Toxicity Characteristic Leaching Procedure (TCLP) was carried out to evaluate the metal stabilization efficiency of the ABC. ${ }^{14} 20 \mathrm{~mL}$ of $0.11 \mathrm{M}$ acetic acid $(\mathrm{pH}$ $=2.83$ ) were added to $1.000 \pm 0.001 \mathrm{~g}$ of air-dried samples in $30 \mathrm{~mL}$ polypropylene centrifugation tubes. The samples were shaken by a mechanical shaker for 20 hours at $150 \mathrm{rpm}$. The extractants were separated from the solid residues by centrifugation at $2800 \mathrm{rpm}$ for $15 \mathrm{~min}$ and filtered through a cellulose nitrate filter of $0.45 \mu \mathrm{m}$ pore size (Sartorius, Germany).

The mobility of $\mathrm{P}$ in mixtures was evaluated by sodium hydrogen carbonate extraction of mixtures following by spectrometric determination of $\mathrm{P}$ according to SIST ISO 11263:1996. The absorbance measurements were carried out at $880 \mathrm{~nm}$.

\section{Results and Discussion}

Total metal concentration, acetic acid and water extractable metal concentrations in tailings and the corresponding legislative limits are presented in Table 2 .

The total concentrations of $\mathrm{Cu}, \mathrm{Zn}, \mathrm{As}$ and $\mathrm{Pb}$ in tailings exceeded the critical limits of dangerous substances

Table 1: Physicochemical properties of the mine tailings and ABC.

\begin{tabular}{lllc}
\hline \multicolumn{1}{c}{ Tailings sample (T) } & & & ABC sample \\
\hline $\mathrm{pH}$ value $\left(\mathrm{CaCl}_{2}\right)$ & $7.46 \pm 0.02$ & $\mathrm{pH}$ value $\left(\mathrm{CaCl}_{2}\right)$ & $7.53 \pm 0.04$ \\
Cation exchange capacity $\left(\mathrm{cmol} \mathrm{kg}^{-1}\right)$ & 6.8 & Available $\mathrm{P}$ content $\left(\mathrm{mg} \mathrm{kg}^{-1}\right)$ & $600 \pm 15$ \\
Reduction potential $(\mathrm{mV})$ & 392 & Total P content $(\%)$ & $15.5 \pm 0.3$ \\
Total C content $(\%)$ & 0.78 & Total C content $(\%)$ & 9.51 \\
Organic C content $(\%)$ & 0.19 & Total N content $(\%)$ & 0.64 \\
Inorganic C content $(\%)$ & 0.59 & Total H content $(\%)$ & 0.94 \\
\hline
\end{tabular}

Table 2: Total metal concentration $\left(\mathrm{mg} \mathrm{kg}^{-1}\right)$, TCLP $\left(\mathrm{mg} \mathrm{L}^{-1}\right)$ and water extractable $\left(\mathrm{mg} \mathrm{L}^{-1}\right)$ metal concentrations in tailings with the corresponding legislative limits.

\begin{tabular}{|c|c|c|c|c|c|c|c|c|}
\hline & $\mathrm{Cr}$ & Co & $\mathbf{N i}$ & $\mathbf{C u}$ & Zn & As & Cd & $\mathbf{P b}$ \\
\hline \multicolumn{9}{|l|}{ Total metal concentration } \\
\hline Conc. $\left(\mathrm{mg} \mathrm{kg}^{-1}\right)$ & 37 & 15 & 33 & 212 & 2423 & 93 & 12 & 3316 \\
\hline${ }^{a}$ Critical level $\left(\mathrm{mg} \mathrm{kg}^{-1}\right)$ & 380 & 240 & 210 & 300 & 720 & 55 & 12 & 530 \\
\hline \multicolumn{9}{|l|}{ TCLP } \\
\hline Conc. $\left(\mathrm{mg} \mathrm{L}^{-1}\right)$ & 0.007 & 0.010 & 0.043 & 0.08 & 7 & 0.030 & 0.046 & 39 \\
\hline Regulatory levels ( $\left.\mathrm{mg} \mathrm{L}^{-1}\right)$ & 5.0 & - & - & - & 250 & 5.0 & 1.0 & 5.0 \\
\hline \multicolumn{9}{|l|}{ Water extracts $(\mathrm{S} / \mathrm{L}=1: 10)$} \\
\hline Conc. $\left(\mathrm{mg} \mathrm{L}^{-1}\right)$ & $<0.002$ & $<0.002$ & $<0.002$ & $<0.002$ & $<0.02$ & $<0.002$ & $<0.002$ & 0.031 \\
\hline${ }^{b}$ Limit value $\left(\mathrm{mg} \mathrm{L}^{-1}\right)$ & 0.3 & - & 0.6 & 0.6 & 18 & 0.3 & 0.03 & 0.3 \\
\hline
\end{tabular}

\footnotetext{
${ }^{a}$ The critical legislative limits of dangerous substances in soil. ${ }^{16}{ }^{b}$ The legislative limits for soil burdening with waste spreading. ${ }^{17}$
} 
in the soil stated in Slovenian legislation, ${ }^{16}$ whereas the concentrations of metals in water extracts were far below the legal limits. ${ }^{17}$ The mobility of metals, evaluated by TCLP, was also quite low, except for $\mathrm{Pb}$ which acetic acid extractable concentrations exceed the TCLP regulatory limits by a factor of almost eight.

The partitioning of metals in tailings determined by modified BCR procedure is presented in Figure $1 . \mathrm{Pb}$ in tailings was mainly partitioned between exchangeable $(29.7 \%)$, residual $(27.0 \%)$ and oxidizable fraction (26.4 $\%)$. The highest proportion of $\mathrm{Cr}$ and As were found in the residual fraction, additionally $\mathrm{Co}, \mathrm{Ni}, \mathrm{Cu}, \mathrm{Zn}$ and $\mathrm{Cd}$ were mainly partitioned in the residual and oxidizable fraction. Small amounts of metals in exchangeable form indicate that the mobility of metals was quite low, except for $\mathrm{Pb}$, which is in agreement with our TCLP results.

The change in $\mathrm{pH}$ values of soil is normally an important mechanism for metal stabilization. ${ }^{13}$ In this study the $\mathrm{pH}$ value of $\mathrm{ABC}$ was just slightly higher than the $\mathrm{pH}$ value of tailings. Therefore, the addition of $\mathrm{ABC}$ to tailings did not significantly change the $\mathrm{pH}$ of the mixtures (values between 7.44 and 7.56) and therefore have negligible influence on metal bioavailability reduction.

The stabilisation of specific elements in mixtures was estimated by comparing TCLP metal concentrations of mixtures to TCLP metal concentrations of tailings (Fig. 2).

The most efficient stabilization of metals was achieved for $\mathrm{Pb}$. The addition of $\mathrm{ABC}$ at application rates of 0.6 $\%, 1.2 \%, 1.8 \%$ and $3.6 \%$ decreased the mobility of $\mathrm{Pb}$ to
$45 \%, 12 \%, 5 \%$ and $3 \%$ of the $\mathrm{Pb}$ mobility in tailings, respectively. Application of $\mathrm{ABC}$ at higher application rates was very effective in reducing the TCLP concentration of $\mathrm{Pb}$ to values lower than the USEPA toxic regulatory level $\left(5 \mathrm{mg} \mathrm{L}^{-1}\right) .{ }^{14} \mathrm{~Pb}$ mobility reduction could be due to the formation of $\mathrm{Pb}$ hydroxyapatite-like minerals $\left(\mathrm{Pb}_{10}\left(\mathrm{PO}_{4}\right)_{6}\right.$ $(\mathrm{OH})_{2}$ ) by precipitation of $\mathrm{Pb}$ and $\mathrm{P}$ released from calcium hydroxyapatite. ${ }^{13}$ As shown in Fig. 2, the mobility of $\mathrm{P}$ gradually increases with respect to increasing application rate of $\mathrm{ABC}$ to tailing, but still remained at environmentally acceptable levels.

High metal stabilization efficiencies were also observed for $\mathrm{Cr}$ and $\mathrm{Cd}$, respectively. Their mobility decreased down to $8 \%(\mathrm{Cr})$ and $63 \%(\mathrm{Cd})$ of original mobility in tailings. For both elements the increase in $\mathrm{ABC}$ addition resulted in increased stabilization efficiency. On the other hand, the effect of $\mathrm{ABC}$ on $\mathrm{Zn}$ mobility was quite small. A significant stabilization effect was observed only at the highest $\mathrm{ABC}$ application rates $(80 \%$ of $\mathrm{Zn}$ mobility in tailings), whereas at low application rates, the effect was even slightly destabilizing. As mentioned in literature, a possible removal mechanism for these three elements, besides metal phosphates precipitation, could be due to sorption mechanisms, like surface complexation and ion exchange. ${ }^{1,9,18}$

Unlike other elements, the mobility of As increased $0.9,1.3,1.5$ and 2.3 times in mixtures $\mathrm{T}-\mathrm{ABC}(0.6)$, $\mathrm{T}-\mathrm{ABC}(1.2), \mathrm{T}-\mathrm{ABC}(1.8)$ and $\mathrm{T}-\mathrm{ABC}(3.6)$, respectively. The highest TCLP concentrations of As was $0.069 \mathrm{mg} \mathrm{L}^{-1}$ $\left(1.39 \mathrm{mg} \mathrm{kg}^{-1}\right)$ and still remained well below the TCLP re-

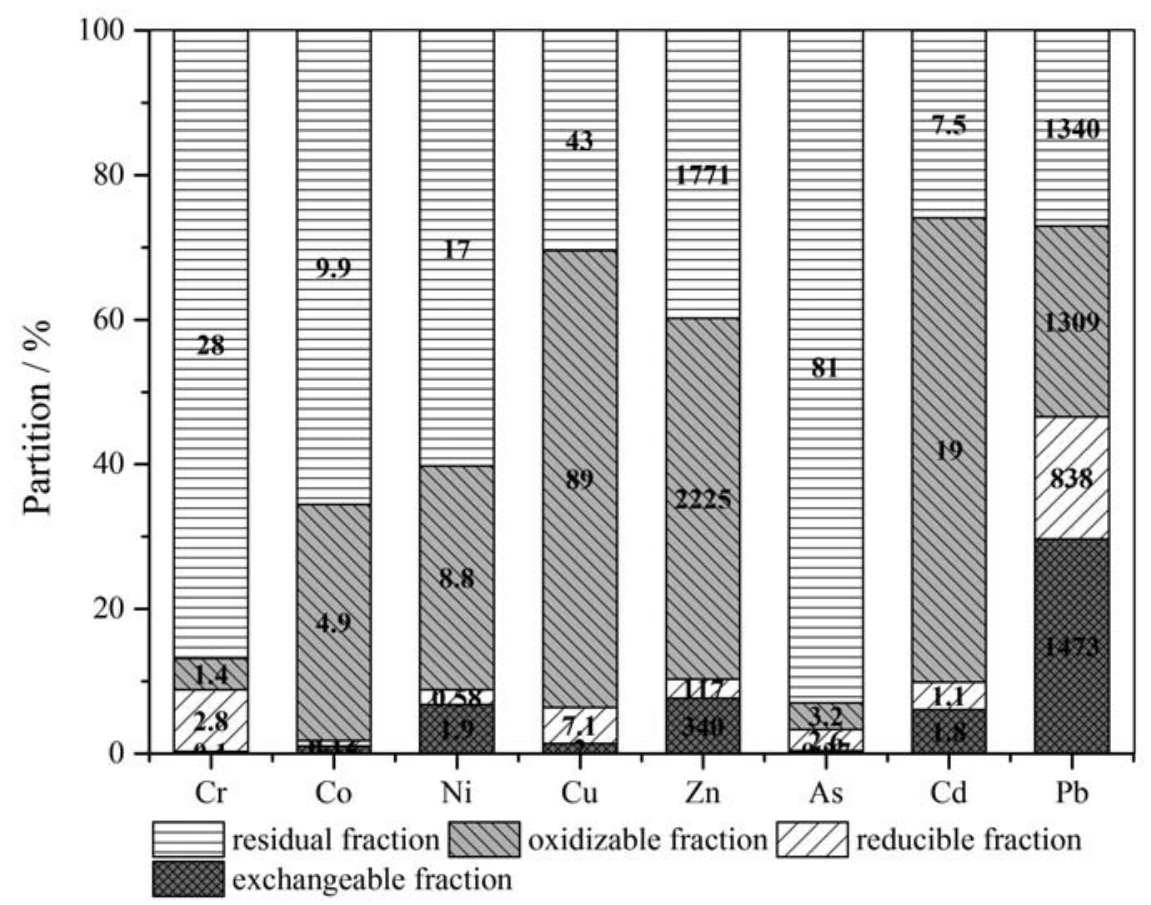

Fig. 1. Partitioning of metals in tailings, determined by modified BCR procedure (with corresponding concentration values in $\mathrm{mg}$ of metal per $\mathrm{kg}$ of tailings). 

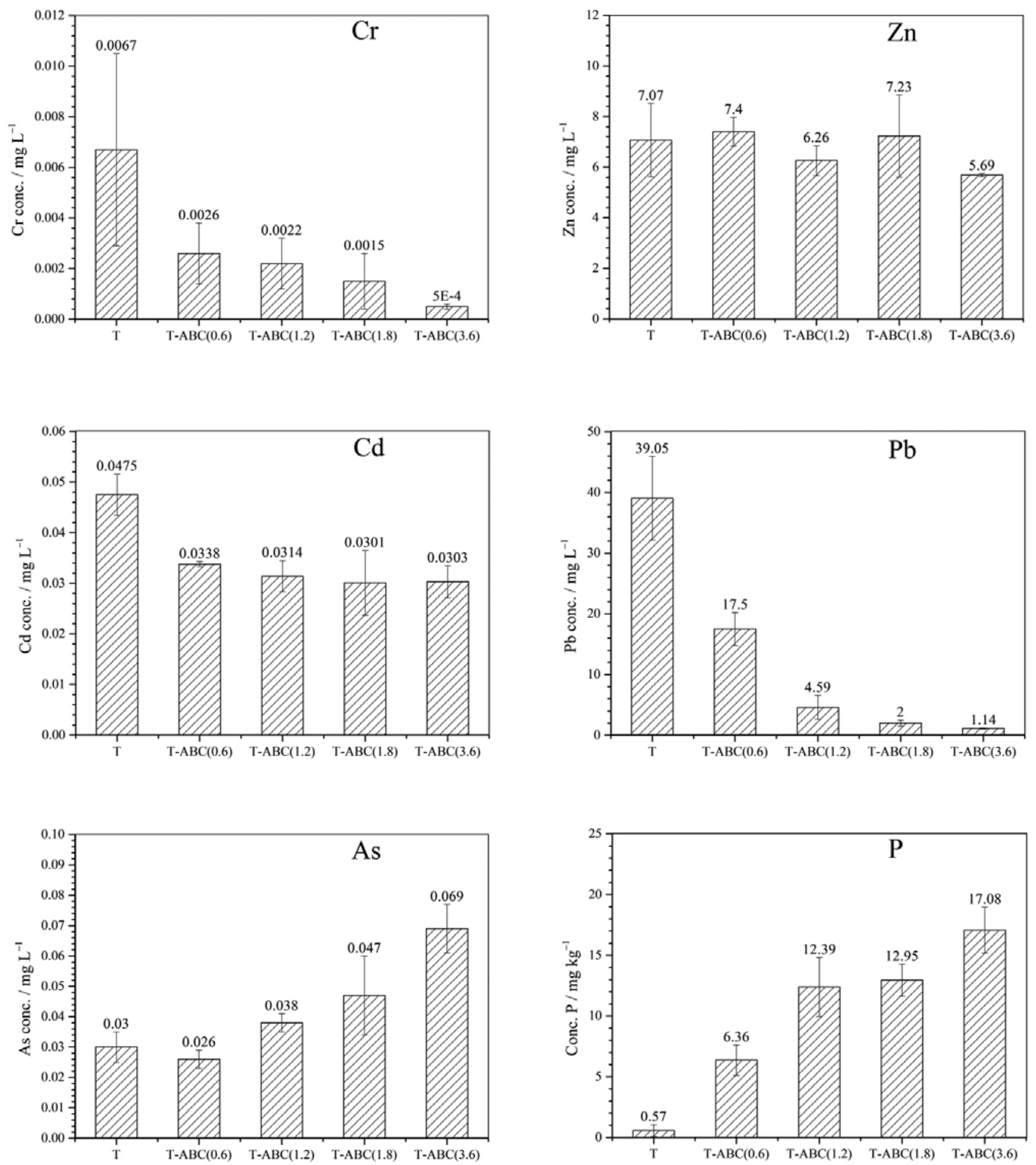

Fig. 2. TCLP concentrations of metals (in $\mathrm{mg} \mathrm{L}^{-1}$ ) and the mobility of $\mathrm{P}\left(\right.$ in $\mathrm{mg} \mathrm{kg}^{-1}$ ) of the tailings and mixtures. Results are presented as the average of three replicates with standard deviations as the error bars.

gulatory value of $5 \mathrm{mg} \mathrm{L}^{-1}$. As(V) species at moderately acidic and neutral $\mathrm{pH}$ can be present as arsenate( $\mathrm{V})$ oxyanions. ${ }^{19}$ Since the arsenate(V) is very similar to phosphate $(\mathrm{V})$, competitive adsorption could occur and result as increased leaching of As. ${ }^{6}$

\section{Conclusions}

The addition of $\mathrm{ABC}$ to the studied multi-element contaminated mine tailings resulted in a considerable reduction of TCLP-extractable $\mathrm{Pb}, \mathrm{Cr}$ and $\mathrm{Cd}$ in mixtures up 
to $3 \%, 8 \%$ and $63 \%$ of concentrations in extracts of tailings, respectively. After the treatment, the concentration of acetic acid extractable $\mathrm{Pb}$ decreased below the regulatory level stated by TCLP. The addition of ABC gradually induced the desorption of the retained As in tailings and the increased concentration of mobile $\mathrm{P}$ in mixtures, but concentrations of As still remained far below TCLP threshold.

In summary, $\mathrm{ABC}$ amendments show promising results as metal-stabilization agents, especially for $\mathrm{Pb}$ immobilization. However, attention should be paid upon $\mathrm{ABC}$ amendments to highly mobile arsenic-metal polluted soil.

\section{Acknowledgements}

This research study was funded by financial support provided by the Ministry of Higher Education, Science and Technology (P1-0134) of the Republic of Slovenia.

\section{References}

1. I. R. Sneddon, M. Orueetxebarria, M. E. Hodson, P. F. Schofield, E. Valsami-Jones, Environ. Pollut. 2006, 144, 816-825. https://doi.org/10.1016/j.envpol.2006.02.008

2. L. Beesley, O. S. Inneh, G. J. Norton, E. Moreno-Jimenez, T. Pardo, R. Clemente, J. J. C. Dawson, Environ. Pollut. 2014, 186, 195-202. https://doi.org/10.1016/j.envpol.2013.11.026

3. G. Fellet, M. Marmiroli, L. Marchiol, Sci. Total Environ. 2014, 468-469, 598-608. https://doi.org/10.1016/j.scitotenv.2013.08.072

4. J. Pérez-Esteban, C. Escolástico, A. Masaguer, C. Vargas, A. Moliner, Chemosphere 2014, 103, 164-171. https://doi.org/10.1016/j.chemosphere.2013.11.055

5. D. Houben, L. Evrard, P. Sonnet, Chemosphere 2013, 92, 1450-1457.

https://doi.org/10.1016/j.chemosphere.2013.03.055
6. M. Zupančič, S. Lavrič, P. Bukovec, J. Environ. Monit. 2012, 14, 704-710. https://doi.org/10.1039/c2em10798h

7. I. R. Sneddon, M. Orueetxebarria, M. E. Hodson, P. F. Schofield, E. Valsami-Jones, Appl. Geochem. 2008, 23, 24142424. https://doi.org/10.1016/j.apgeochem.2008.02.028

8. Z. Y. Huang, J. Li, Y. L. Cao, C. Cai, Z. Zhang, Geoderma 2016, 264, 126-131. https://doi.org/10.1016/j.geoderma.2015.10.013

9. X. W. Hao, Y. Z. Huang, Y. S. Cui, Acta Ecol. Sin. 2010, 30, 118-122. https://doi.org/10.1016/j.chnaes.2010.03.012

10. M. J. Zwetsloot, J. Lehmann, T. Bauerle, S. Vanek, R. Hestrin, A. Nigussie, Plant Soil 2016, 408, 95-105. https://doi.org/10.1007/s11104-016-2905-2

11. U. Iriarte-Velasco, J. L. Ayastuy, L. Zudaire, I. Sierra, Chem. Eng. J. 2014, 251, 217-227. https://doi.org/10.1016/j.cej.2014.04.048

12. J. C. Moreno-Piraján, R. Gómez-Cruz, V. S. García-Cuello, L. Giraldo, J. Anal. Appl. Pyrol. 2010, 89, 122-128. https://doi.org/10.1016/j.jaap.2010.06.007

13. S. B. Chen, Y. G. Zhu, Y. B. Ma, G. McKay, Environ. Pollut. 2006, 139, 433-439. https://doi.org/10.1016/j.envpol.2005.06.007

14. USEPA, SW-846: Test Methods for Evaluating Solid Waste, Physical/Chemical Methods, Analytical Method 1311: Toxicity Characteristic Leaching Procedure, Washington, DC, 2008.

15. G. Rauret, J. F. Lopez-Sanchez, A. Sahuquillo, R. Rubio, C. Davidson, A. Ure, Ph. Quevauviller, J. Environ. Monit. 1999, 1, 57-61. https://doi.org/10.1039/a807854h

16. Official Gazette of RS, Decree on the limit, warning and critical levels of hazardous substances in the soil, Nos. 68/96 and 41/04 - ZVO-1, 1996.

17. Official Gazette of RS, Decree on burdening the soil by waste, Nos. 34/08 and 61/11, 2008.

18. A. H. M. G. Hyder, S. A. Begum, N. O. Egiebor, J. Environ. Chem. Eng. 2015, 3, 1329-1336. https://doi.org/10.1016/j.jece.2014.12.005

19. H. Jin, S. Capareda, Z. Chang, J. Gao, Y. Xu, J. Zhang, Bioresour. Technol. 2014, 169, 622-629. https://doi.org/10.1016/j.biortech.2014.06.103

\section{Povzetek}

Namen našega raziskovalnega dela je bil proučiti vpliv dodatka biooglja, pripravljenega iz živalskih kosti (ABC), na mobilnost kovin v jalovinskem materialu. Jalovinskemu materialu smo dodali štiri različne deleže ABC $(0.6 \mathrm{~g}, 1.2 \mathrm{~g}$, $1.8 \mathrm{~g}$ in $3.6 \mathrm{~g}$ ABC na $100 \mathrm{~g}$ jalovine) in določili mobilnost kovin s pomočjo enostopenjske ekstrakcije $\mathrm{z} 0,11 \mathrm{M}$ ocetno kislino (TCLP Toxicity Characteristic Leaching Procedure). Rezultati so pokazali, da se mobilnost $\mathrm{Pb}, \mathrm{Cr}$ in Cd postopoma zmanjšuje z naraščajočo količino dodanega $\mathrm{ABC}$. Pb je s stališča mejnih vrednosti, določenih s strani TCLP, predstavljal edini problematični element v vzorcu. Koncentracija $\mathrm{Pb} v$ ocetnokislinskih ekstraktih se je pri treh višjih dodatkih ABC zmanjšala z $39 \mathrm{mg} \mathrm{L}^{-1}$ na vrednosti, ki so bile pod mejno vrednostjo TCLP testa $\left(5 \mathrm{mg} \mathrm{L}^{-1}\right)$. Rezultati so pokazali uporabnost ABC kot učinkovitega stabilizacijskega sredstva za s kovinami onesnažena tla. 